\title{
STUDI PENGARUH PREHEAT DAN POST HEAT TERHADAP SIFAT MEKANIK ALUMINIUM 6061 DENGAN PENGELASAN TUNGSTEN INERT GAS
}

\author{
Rendi K. Gurusinga ${ }^{1 *}$, Alfian Hamsi ${ }^{2}$, Indra ${ }^{3}$, Ahmad H. Siregar ${ }^{4}$, Mahadi $^{5}$ \\ 1,2,3,4,5 Departemen Teknik Mesin, Fakultas Teknik, Universitas Sumatera Utara \\ Email: rendi.gurusinga@gmail.com
}

\begin{abstract}
Abstrak
Teknologi produksi dengan menggunakan bahan baku logam, teknik penyambungan logam dengan pengelasan merupakan proses pengerjaan yang memegang peranan yang sangat penting. Salah satu jenis pengelasan yang sudah umum digunakan adalah pengelasan Tungsten Inert Gas (TIG) untuk menyambung logam seperti Aluminium, Stainless Steel, Carbon Steel, dan Tembaga. Ada beberapa parameter yang menpengaruhi hasil las seperti yaitu arus, sifat logam induk, logam pengisi, preheat dan post heat, dll. Adapun tujuan dari studi ini adalah untuk mengetahui pengaruh preheat dan post heat yang sifat mekanik dari Aluminium 6061 menggunakan variasi preheat dan post heat pada temperatur $130^{\circ} \mathrm{C}$, $160^{\circ} \mathrm{C}$, dan $190^{\circ} \mathrm{C}$ dengan pengelasan TIG. Tujuan perlakuan preheat adalah untuk mengurangi kelembaban area pengelasan, mencegah terjadinya craking pada pengelasan.. Dan tujuan pemberian post heat adalah untuk menghilangkan tegangan sisa yang terjadi pada hasil pengelasan. Pada hasil studi ini didapat bahwa sifat mekanik dari pengelasan Aluminium 6061 mengalami perubahan berdasarkan variasi preheat dan post heat yang telah dilakukan. Nilai kekerasan titik las meningkat dimana pada temperature $130^{\circ} \mathrm{C}=68,72 \mathrm{BHN}, 160^{\circ} \mathrm{C}=70,51 \mathrm{BHN}$, dan $190^{\circ} \mathrm{C}=76,26 \mathrm{BHN}$. Dan untuk kekuatan tarik juga mengalami peningkatan dimana pada temperature $130^{\circ} \mathrm{C}=158,57 \mathrm{~N} / \mathrm{mm}^{2}, 160^{\circ} \mathrm{C}=169,85 \mathrm{~N} / \mathrm{mm}^{2}$, dan $190^{\circ} \mathrm{C}=174,50 \mathrm{~N} / \mathrm{mm}^{2}$.
\end{abstract}

Kata kunci: Pengelasan TIG, Aluminium 6061, Preheat, Post heat.

\begin{abstract}
In manufacturing technology using metal raw materials, the technique of joining metals with welding is a work process that very important. One type of welding that is commonly used is the welding of Tungsten Inert Gas (TIG) to join metals such as Aluminum, Stainless Steel, Carbon Steel, and Copper. There are several parameters that affect the weld results such as electric current of welding, metal properties, filler metal, preheat and post heat, etc. The purpose of this study was to determine the effect of preheat and post heat on the mechanical properties of Aluminum 6061 using preheat and post heat variations at temperatures of $130^{\circ} \mathrm{C}, 160^{\circ} \mathrm{C}$, dan $190^{\circ} \mathrm{C}$ with $\mathrm{TIG}$ welding. The purpose of the preheat treatment is to reduce the welding area humidity, preventing the occurrence of craking of welds, improving toughness. And the purpose of the post heat treatment is for relieving the residual stress that occurs in the welding results. In the results of this study it was found that the mechanical properties of Aluminum 6061 welding has changed according to the preheat and post heat variations that have been done. The value of weld metal hardness increases where at temperature $130^{\circ} \mathrm{C}=68,72 \mathrm{BHN}$, $160^{\circ} \mathrm{C}=70,51 \mathrm{BHN}$, dan $190^{\circ} \mathrm{C}=76,26 \mathrm{BHN}$. And for tensile strength also increased where at a temperature of $130^{\circ} \mathrm{C}=158,57 \mathrm{~N} / \mathrm{mm}^{2}, 160^{\circ} \mathrm{C}=169,85 \mathrm{~N} / \mathrm{mm}^{2}$, dan $190^{\circ} \mathrm{C}=174,50 \mathrm{~N} / \mathrm{mm}^{2}$.
\end{abstract}

Keywords: TIG Welding, Aluminium 6061, Preheat, Post heat.

\section{Pendahuluan}

Aluminium merupakan nonferrous metal, dimana aluminium memiliki sifat yang menguntungkan seperti tahan terhadap korosi, konduktor panas yang baik serta ringan. Namun jika dibandingkan dengan baja, aluminium mempunyai sifat yang kurang baik dalam pengelasan. Tidak semua jenis mesin las yang cocok untuk melakukan pengelasan pada material 
aluminium. Salah satu teknik pengelasan yang dapat digunakan dalam pengelasan aluminium adalah las Tungsten Inert Gas (TIG) atau Gas Tungsten Arc Welding (GTAW).

Selain itu parameter yang dapat mempengaruhi hasil-hasil pengelasan, yaitu arus, sifat logam induk, logam pengisi, preheat, post heat dsb. Funderburk (1997), menganjurkan pemansan mula (preheat) dan penahanan panas (post heat) ketika menggunakan pengelasan sambungan aluminium yang tebalnya diatas $6 \mathrm{~mm}$. Jika perlakuan panas tidak dilakukan sebelum atau setelah pengelasan maka akan menghasilkan lasan yang jauh dari sifat kedua logam yang akan disambung. Preheat dan post heat atau biasa juga disebut post weld heat treatment (PWHT) merupakan suatu perlakuan panas yang dilakukan pada pengelasan. Yang mana kedua parameter ini dapat mempengaruhi hasil dari pengelasan. Pada skripsi ini akan dicari tahu pengaruh kedua parameter tersebut terhadap sifat mekanik pada proses pengelasan dengan menggunakan mesin las Tungsten Inert Gas (TIG).

Penelitian kali ini mengunakan aluminium alloy 6061, yang mana aluminium ini merupakan salah satu jenis dari aluminium paduan. Paduan aluminium 6xxx banyak dipakai pada konstruksi dan aplikasi otomotif. Untuk mendapatkan peningkatan kekuatan mekanik, biasanya logam aluminium akan dipadukan dengan unsur lain seperti $\mathrm{Cu}, \mathrm{Si}, \mathrm{Mg}, \mathrm{Mn}, \mathrm{Ni}$, dan unsur-unsur lainnya. Pada aluminium alloy 6061 itu sendiri merupakan jenis aluminium paduan dengan unsur magnesium dan silicon. Jenis aluminium paduan ini memiliki sifat yang mudah dibentuk, memiliki ketahanan terhadap korosi serta konduktivitas termal yang cukup baik. Dibalik sifat-sifat baik yang dimiliki aluminium paduan ini, Aluminium alloy 6061 juga merupakan jenis aluminum yang mudah didapat dipasaran dan cukup banyak digunakan.

Tujuan dilakukannya penelitian ini adalah untuk pengaruh dari perlakuan preheat dan post heat pada hasil pengelasan Tungsten Inert Gas (TIG) terhadap sifat mekanik dari aluminium alloy 6061 berupa nilai kekuatan tarik dan nilai kekerasan dari spesimen tersebut serta mengetahui bentuk struktur mikro dari aluminium alloy 6061 yang sudah menerima pengaruh preheat dan post heat.

\section{Metode}

Proses pembuatan spesimen dilakukan di Laboratorium Teknologi Mekanik Departemen Teknik Mesin Universitas Sumatera Utara. Pengujian tarik (tensile test) dilakukan di Laboratorium Pengujian Logam Departemen Teknik Mesin Politeknik Negeri Medan, dan pengujian kekerasan (hardness test) dan pengamatan struktur mikro dilakukan di Laboratorium Metalurgi Departemen Teknik Mesin Universitas Sumatera Utara.

Bahan yang digunakan adalah Aluminium alloy 6061 dengan Al 6061mempunyai titik cair (melting point) $660^{\circ} \mathrm{C}$. kekuatan tarik $126 \mathrm{~N} / \mathrm{mm}^{2}$ sampai $461,9 \mathrm{~N} / \mathrm{mm}^{2}$, berat jenis 
(density) $2,70 \mathrm{~g} / \mathrm{cm}^{3}$, ekspansi thermal (linier coefficient of thermal) $13,1.10^{-6} \mathrm{in} / \mathrm{in} /{ }^{0} \mathrm{~F}$ dan themal conductifity pada $25^{\circ} \mathrm{C}, 23 \mathrm{w} / \mathrm{cm} /{ }^{\circ} \mathrm{C}$ (Schwartz. Mel M,1992)

Tabel 2.1. Komposisi Kimia aluminium alloy $6061(\%)$

\begin{tabular}{|c|l|l|l|l|l|l|l|l|l|c|}
\hline $\mathbf{A l}$ & $\mathbf{S i}$ & $\mathbf{F e}$ & $\mathbf{C u}$ & $\mathbf{M n}$ & $\mathbf{M g}$ & $\mathbf{M n}$ & $\mathbf{C r}$ & $\mathbf{Z n}$ & $\mathbf{T i}$ & Lainnya \\
\hline 97,32 & 0,69 & 0,5 & 0,22 & 0,11 & 0,86 & 0,15 & 0,15 & 0,11 & 0,05 & 0,02 \\
\hline
\end{tabular}

Aluminium 6061 dilas menggunakan las Tungsten Inert Gas (TIG) dengan filler ER5356, dengan kuat arus 80 Ampere. Spesimen untuk pengujian kekerasan menggunakan standararisasi ASTM E-10 dengan dimensi seperti gambar 2.1a dibawah, dan spesimen ini juga akan digunakan untuk melakukan uji struktur mikro. Untuk pengujian tarik menggunakan standarisasi ASTM E-8 seperti gambar 2.1b dibawah.

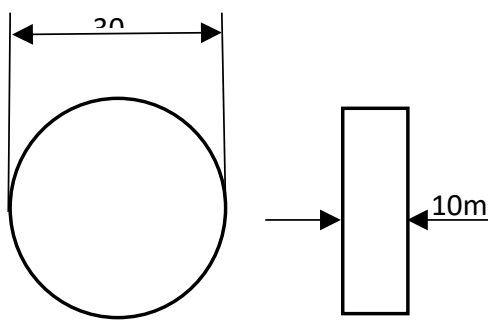

(a)

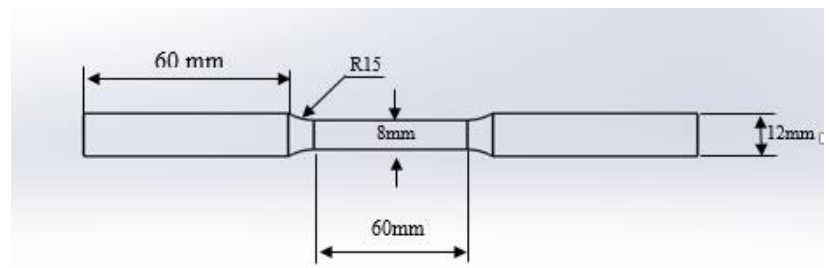

(b)

\section{Gambar 2.1 Spesimen ASTM E-10 (a), Spesimen ASTM E-8 (b)}

\subsection{Metode Numerik}

Pada metode numerik ini adapun persamaan yang digunakan dalam pengujian diantaranya:

1. Uji tarik (tensile test)

Untuk mengetahui tegangan pada pengujian tarik secara matematis dapat ditulis:

$\sigma=\frac{P}{A}$

Sementara untuk mengetahui regangan yang terjadi secara matematis dapat ditulis:

$\varepsilon=\frac{\Delta l}{L o} x 100 \%$

Untuk mengetahaui modulus elatisitas secara matematis dapat ditulis:

$E=\frac{\sigma}{e}$

Dimana : $\sigma=$ Tegangan $(\mathrm{Mpa}), \mathrm{P}=$ gaya, $\mathrm{A}=$ Luas penampang $\left(\mathrm{cm}^{2}\right), \varepsilon=$ Regangan, $\Delta l=$ Pertambahan panjang $(\mathrm{cm}), \mathrm{L}_{0}=$ Panjang mula-mula $(\mathrm{cm})$ 
2. Uji kekerasan (hardness test)

Untuk mengetahui nilai kekerasan secara matematis dapat ditulis:

$$
B H N=\frac{P}{\frac{\pi D}{2}\left(D^{2}-d^{2}\right)}
$$

Dimana : D = Diameter bola indentor $(\mathrm{mm}), \mathrm{d}=$ Diameter indentasi $(\mathrm{mm}) \mathrm{P}=$ Beban (kgf), BHB = Brinell Hardness Number .

\subsection{Diagram Alir Penelitian}

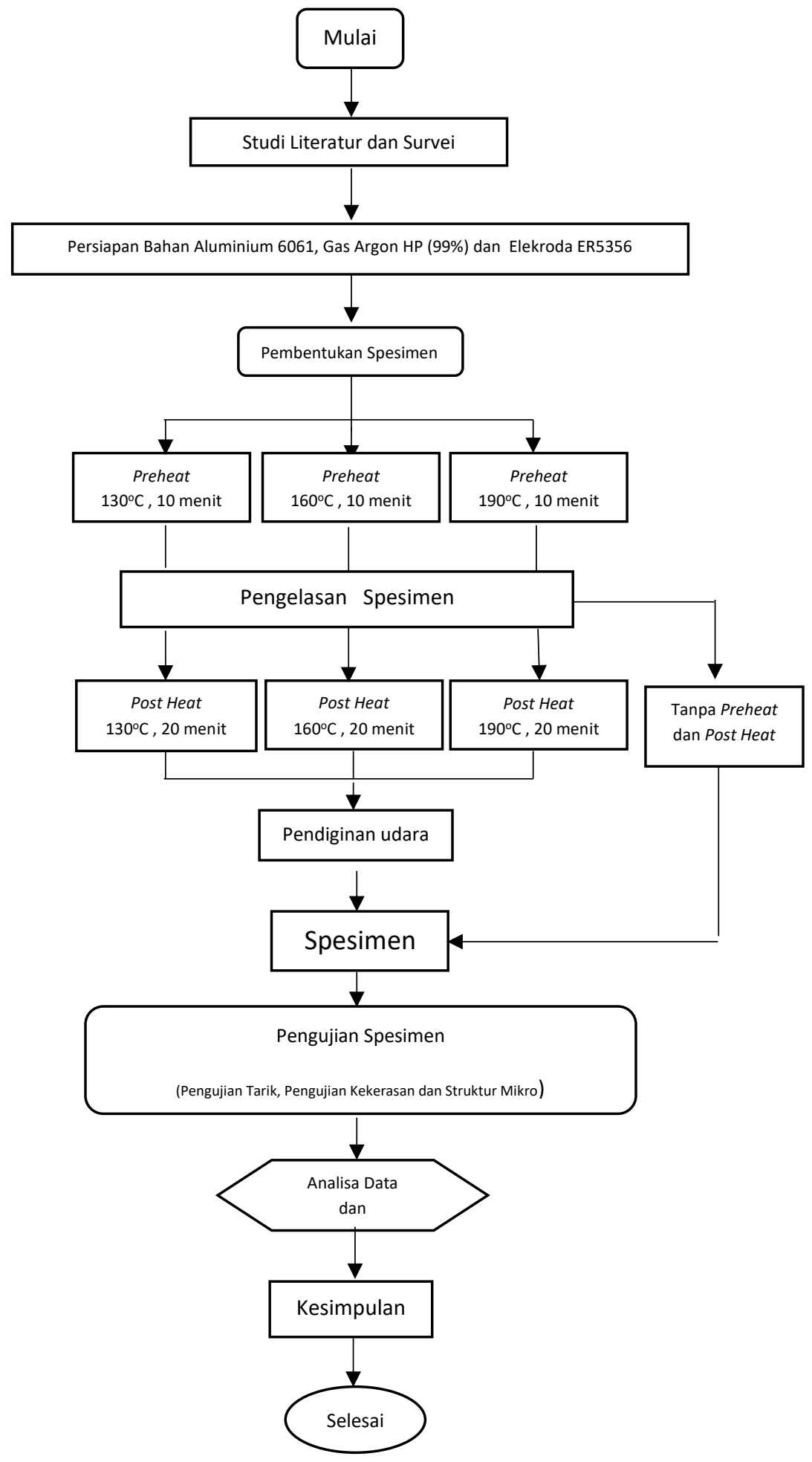




\section{Gambar 2.2 Diagram Alir Penelitian}

\section{Analisis dan Pembahasan}

\subsection{Uji Kekerasan}

Pengujian kekerasan pada studi ini menggunkaan metode Brinell . tujuan dari dilakukan pengujian ini untuk mengetahui perubahan nilai kekerasan yang disebabkan oleh pengaruh preheat dan post heat yang dilakukan pada pengelasan aluminium 6061 pada daerah logam las serata daerah HAZ. Ukuran bola indentor adalah $5 \mathrm{~mm}$ dengan pembebanan $500 \mathrm{~N}$ selama 5 detik.

Tabel 3.1 Hasil pengujian Kekerasan

\begin{tabular}{|c|c|c|c|c|c|}
\hline \multirow{2}{*}{ Daerah Uji } & \multirow{2}{*}{$\begin{array}{c}\text { Titik } \\
\text { Uji }\end{array}$} & \multicolumn{2}{|c|}{$\begin{array}{l}\text { Diameter } \\
\text { Indentasi }\end{array}$} & \multicolumn{2}{|c|}{$\begin{array}{c}\text { Nilai Kekerasan } \\
(\mathrm{BHN})\end{array}$} \\
\hline & & $\begin{array}{l}\text { Titik } \\
\text { Las }\end{array}$ & HAZ & $\begin{array}{l}\text { Titik } \\
\text { Las }\end{array}$ & HAZ \\
\hline \multirow{4}{*}{$\begin{array}{l}\text { Tanpa preheat dan post } \\
\text { heat }\end{array}$} & $\mathrm{i}$ & 3 & 3,2 & 63,69 & 55,00 \\
\hline & ii & 3 & 3 & 63,69 & 63,69 \\
\hline & iii & 2,9 & 3,1 & 68,72 & 59,14 \\
\hline & $\begin{array}{l}\text { Rata- } \\
\text { rata }\end{array}$ & 2,97 & 3,10 & 65,31 & 59,14 \\
\hline \multirow{4}{*}{$\begin{array}{l}\text { Preheat dan post heat } \\
\qquad 130^{\circ} \mathrm{C}\end{array}$} & $\mathrm{i}$ & 2,9 & 3 & 68,72 & 63,69 \\
\hline & ii & 2,9 & 3 & 68,72 & 63,69 \\
\hline & iii & 2,9 & 3,1 & 68,72 & 59,14 \\
\hline & $\begin{array}{l}\text { Rata- } \\
\text { rata }\end{array}$ & 2,93 & $3, \mathbf{0 3}$ & 68,72 & 62,13 \\
\hline \multirow{4}{*}{$\begin{array}{l}\text { Preheat dan post heat } \\
\qquad 160^{\circ} \mathrm{C}\end{array}$} & $\mathrm{i}$ & 2,8 & 2,9 & 74,28 & 68,72 \\
\hline & ii & 2,9 & 3 & 68,72 & 63,69 \\
\hline & iii & 2,9 & 3 & 68,72 & 63,69 \\
\hline & $\begin{array}{l}\text { Rata- } \\
\text { rata }\end{array}$ & 2,87 & 2,97 & 70,51 & 65,31 \\
\hline \multicolumn{6}{|l|}{ Preheat dan post heat } \\
\hline $190^{\circ} \mathrm{C}$ & $\mathrm{i}$ & 2,8 & 2,9 & 74,28 & 68,72 \\
\hline & ii & 3,8 & 2,9 & 74,28 & 68,72 \\
\hline & iii & 3,7 & 2,8 & 80,46 & 74,28 \\
\hline
\end{tabular}




\begin{tabular}{|c|c|c|c|c|c|}
\hline & $\begin{array}{c}\text { Rata- } \\
\text { rata }\end{array}$ & 2,77 & 2,87 & 76,26 & 70,51 \\
\hline \multirow[t]{4}{*}{ Base metal } & $\mathrm{i}$ & \multicolumn{2}{|c|}{2,5} & \multicolumn{2}{|c|}{95,08} \\
\hline & ii & \multicolumn{2}{|c|}{2,5} & \multicolumn{2}{|c|}{95,08} \\
\hline & iii & \multicolumn{2}{|c|}{2,4} & \multicolumn{2}{|c|}{103,79} \\
\hline & $\begin{array}{c}\text { Rata- } \\
\text { rata }\end{array}$ & \multicolumn{2}{|c|}{2,47} & \multicolumn{2}{|c|}{97,87} \\
\hline
\end{tabular}

Dari hasil pengujian kekerasan didapat bahwa terjadinya peningkatan nilai kekerasan pada pengaruh preheat dan post heat pada pengelasan aluminium 6061. Grafik dari pengujian kekerasan dapat dilihat pada gambar 3.1

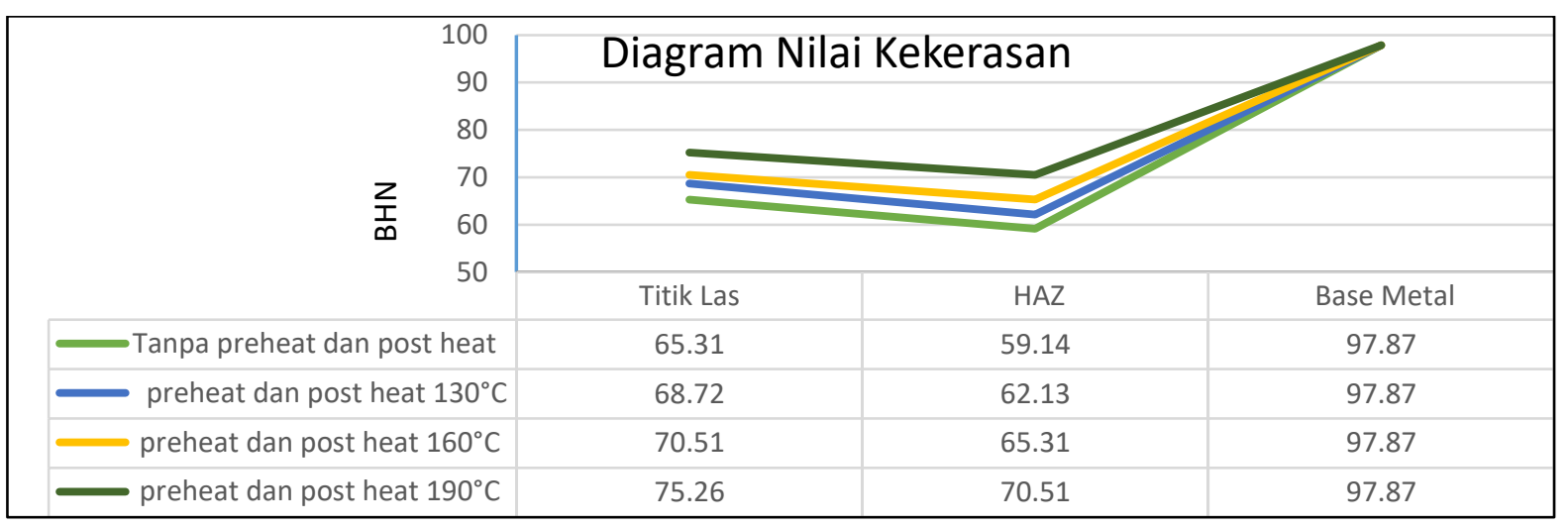

Gambar 3.1 Diagram Nilai Kekerasan

\subsection{Uji Tarik}

Dari hasil pengujian tarik titik putus terjadi pada daerah HAZ ini terjadi karena nilai kekerasan didaerah HAZ lebih rendah dibandingkan dengan titik las. Untuk data hasil pengujian tarik dapat dilihat pada table 3.2

Tabel 3.2 Hasil Peengujian Tarik

\begin{tabular}{|c|c|c|c|c|c|c|c|c|c|}
\hline Spesimen & $\begin{array}{l}\text { No. } \\
\text { uji }\end{array}$ & $\begin{array}{c}\text { Do } \\
(\mathrm{mm} \\
)\end{array}$ & $\begin{array}{l}\text { Lo } \\
(\mathrm{mm} \\
\quad)\end{array}$ & $\begin{array}{c}\mathrm{Li} \\
(\mathrm{mm} \\
)\end{array}$ & $\begin{array}{c}\text { Ao } \\
\left(\mathrm{mm}^{2}\right)\end{array}$ & $\begin{array}{l}\mathrm{Fu} \\
(\mathrm{N})\end{array}$ & $\begin{array}{c}\sigma \\
(\mathrm{N} / \mathrm{mm} 2 \\
)\end{array}$ & $\begin{array}{c}\mathrm{e} \\
(\%)\end{array}$ & E \\
\hline \multirow{4}{*}{$\begin{array}{c}\text { Pengelasan tanpa } \\
\text { preheat dan post } \\
\text { heat }\end{array}$} & $\mathrm{i}$ & 8 & 48 & $\begin{array}{c}53,4 \\
8\end{array}$ & 50,24 & 8000 & 159,24 & $\begin{array}{c}11,4 \\
2\end{array}$ & $\begin{array}{c}13,9 \\
5\end{array}$ \\
\hline & ii & 8 & 48 & $\begin{array}{c}53,1 \\
1\end{array}$ & 50,24 & 7200 & 143,31 & $\begin{array}{c}10,6 \\
5\end{array}$ & $\begin{array}{c}13,4 \\
6\end{array}$ \\
\hline & iii & 8 & 48 & $\begin{array}{c}52,8 \\
9\end{array}$ & 50,24 & 8200 & 163,22 & $\begin{array}{c}10,1 \\
9\end{array}$ & $\begin{array}{c}16,0 \\
2\end{array}$ \\
\hline & $\begin{array}{l}\text { Rata } \\
\text {-rata }\end{array}$ & 8,00 & $\begin{array}{c}48,0 \\
0\end{array}$ & $\begin{array}{c}53,1 \\
6\end{array}$ & 50,24 & 7800 & 155,25 & $\begin{array}{c}10,7 \\
5\end{array}$ & $\begin{array}{c}14,4 \\
4\end{array}$ \\
\hline $\begin{array}{l}\text { Pengelasan dengan } \\
\text { preheat dan post }\end{array}$ & $\mathrm{i}$ & 8 & 48 & $\begin{array}{c}53,6 \\
2\end{array}$ & 50,24 & 7900 & 157,25 & $\begin{array}{c}11,7 \\
1\end{array}$ & $\begin{array}{c}13,4 \\
3\end{array}$ \\
\hline heat $130^{\circ} \mathrm{C}$ & ii & 8 & 48 & 53,5 & 50,24 & 7500 & 149,28 & 11,5 & 12,9 \\
\hline
\end{tabular}




\begin{tabular}{|c|c|c|c|c|c|c|c|c|c|}
\hline & $\mathrm{iii}$ & 8 & 48 & $\begin{array}{c}4 \\
53,2 \\
4\end{array}$ & 50,24 & 8500 & 169,19 & $\begin{array}{c}4 \\
10,9 \\
2\end{array}$ & $\begin{array}{c}3 \\
15,5 \\
0\end{array}$ \\
\hline & $\begin{array}{l}\text { Rata } \\
\text {-rata }\end{array}$ & 8,00 & 48 & $\begin{array}{c}53,4 \\
6 \\
\end{array}$ & 50,24 & $\begin{array}{c}7966,6 \\
7 \\
\end{array}$ & 158,57 & $\begin{array}{c}11,3 \\
9\end{array}$ & $\begin{array}{c}13,9 \\
2\end{array}$ \\
\hline \multirow{4}{*}{$\begin{array}{l}\text { Pengelasan dengan } \\
\text { preheat dan post } \\
\text { heat } 160^{\circ} \mathrm{C}\end{array}$} & $\mathrm{i}$ & 8 & 48 & $\begin{array}{c}54,3 \\
1\end{array}$ & 50,24 & 9100 & 181,13 & $\begin{array}{c}13,1 \\
5\end{array}$ & $\begin{array}{c}13,7 \\
8\end{array}$ \\
\hline & ii & 8 & 48 & $\begin{array}{c}53,7 \\
4\end{array}$ & 50,24 & 8000 & 159,24 & $\begin{array}{c}11,9 \\
6\end{array}$ & $\begin{array}{c}13,3 \\
2\end{array}$ \\
\hline & iii & 8 & 48 & $\begin{array}{c}53,8 \\
3 \\
\end{array}$ & 50,24 & 8500 & 169,19 & $\begin{array}{c}12,1 \\
5 \\
\end{array}$ & $\begin{array}{c}13,9 \\
3\end{array}$ \\
\hline & $\begin{array}{l}\text { Rata } \\
\text {-rata }\end{array}$ & 8,00 & $\begin{array}{c}48,0 \\
0\end{array}$ & $\begin{array}{c}53,9 \\
6 \\
\end{array}$ & 50,24 & $\begin{array}{c}8533,3 \\
\mathbf{3} \\
\end{array}$ & 169,85 & $\begin{array}{c}12,4 \\
2\end{array}$ & $\begin{array}{c}13,6 \\
8\end{array}$ \\
\hline \multirow{4}{*}{$\begin{array}{l}\text { Pengelasan dengan } \\
\text { preheat dan post } \\
\text { heat } 190^{\circ} \mathrm{C}\end{array}$} & $\mathrm{i}$ & 8 & 48 & $\begin{array}{c}54,7 \\
7\end{array}$ & 50,24 & 8600 & 171,18 & $\begin{array}{c}14,1 \\
0\end{array}$ & $\begin{array}{c}12,1 \\
4\end{array}$ \\
\hline & ii & 8 & 48 & $\begin{array}{c}53,8 \\
5\end{array}$ & 50,24 & 8700 & 173,17 & $\begin{array}{c}12,1 \\
9\end{array}$ & $\begin{array}{c}14,2 \\
1\end{array}$ \\
\hline & iii & 8 & 48 & $\begin{array}{c}54,5 \\
4\end{array}$ & 50,24 & 9000 & 179,14 & $\begin{array}{c}13,6 \\
3\end{array}$ & $\begin{array}{c}13,1 \\
5\end{array}$ \\
\hline & $\begin{array}{l}\text { Rata } \\
\text {-rata }\end{array}$ & 8,00 & 48 & $\begin{array}{c}54,3 \\
9\end{array}$ & 50,24 & $\begin{array}{c}8766,6 \\
7\end{array}$ & 174,50 & $\begin{array}{c}13,3 \\
1\end{array}$ & $\begin{array}{c}13,1 \\
1\end{array}$ \\
\hline
\end{tabular}

Dari pengujian tarik diketahui bahawa terjadinya perubahan sifat mekanik pada spesimen, dimana kekuatan tarik tarik meningkat terhadap pemberian preheat dan post heat. Serta regangannya juga ikut mengalami peningkatan dan berdasarkan modulus elastisitasnya

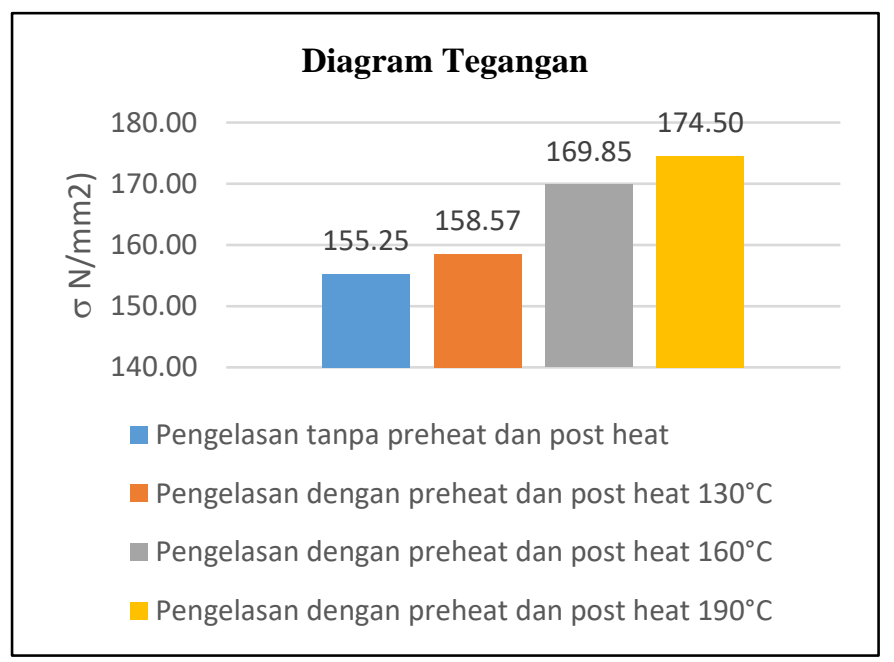

spesimen mengalami penurunan kekakuan. Data hasil pengujian tarik dapat dilihat pada gambar

(a) 


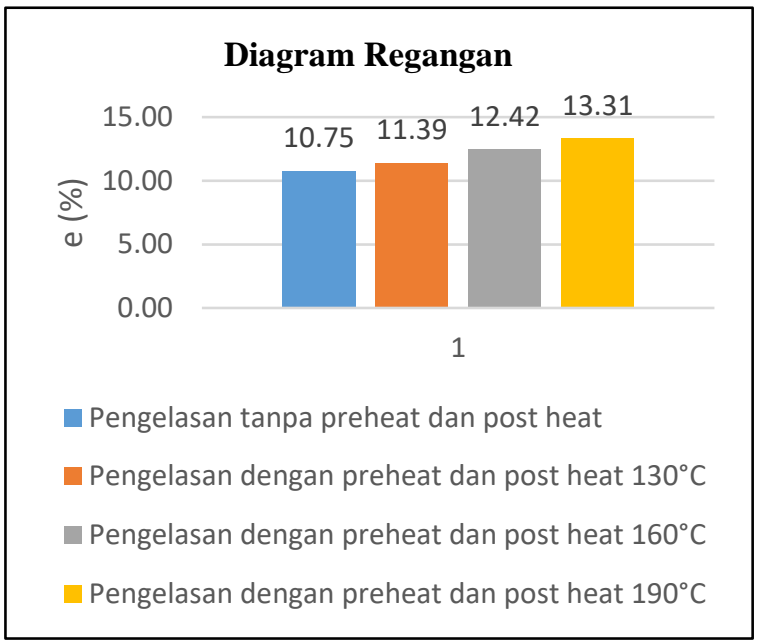

(b)

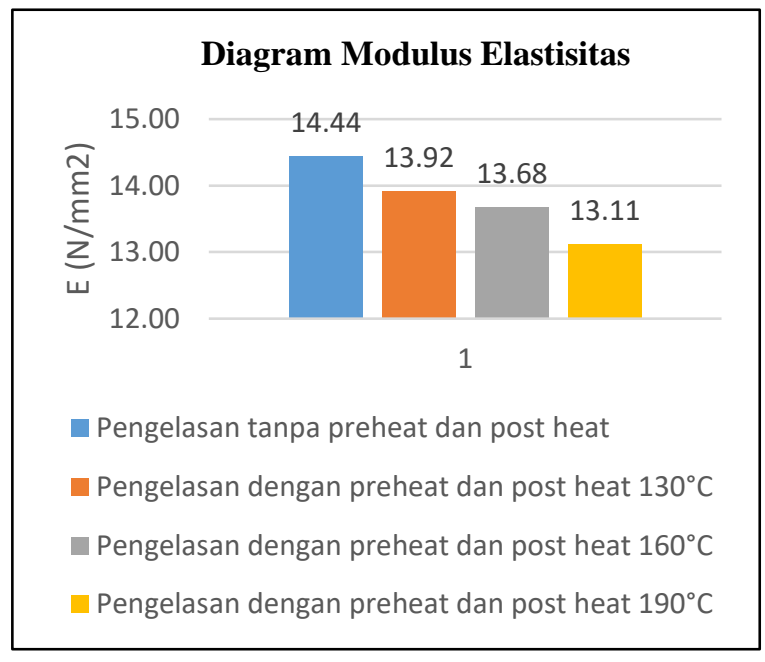

(c)

Gambar 3.2 (a) Diagram Tegangan Rata-rata ;(b) Diagram Regangan Rata-rata; (c) Diagram Modulus Elastisitas

\subsection{Pengamatan Struktur Mikro}

Pengujian mikrostruktur dilakukan dengan menggunakan "Reflected Metallurgical Microscope" dengan type Rax Vision No.545491, MM -10A,230V-50Hz. Pengamatan struktur mikro ini dilakukan pada spesimen aluminium alloy 6061 yang telah dilakukan pengelasan menggunakan las Tungsten Inert Gas (TIG) dengan kuat arus 80. Gambar struktur mikro dapat dilihat pada gambar dibawah.

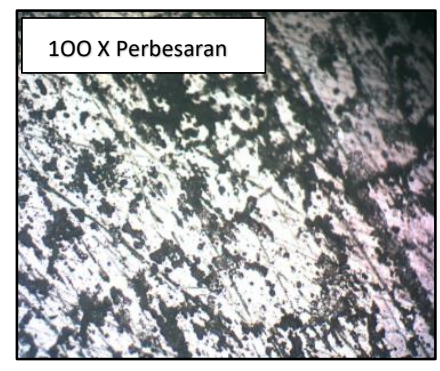

(a)

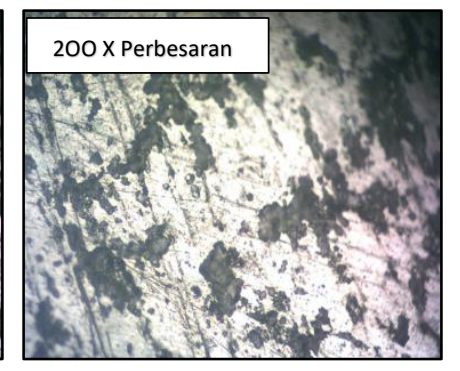

(b)

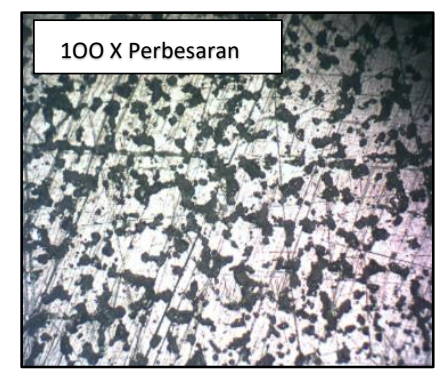

(c)

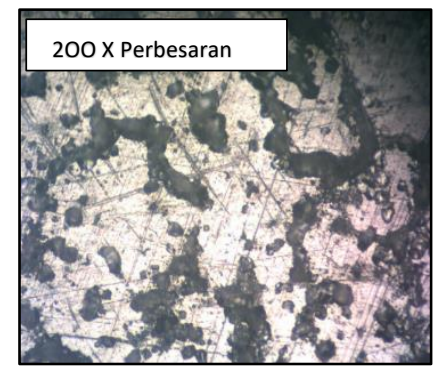

(d)

Gambar 3.3 (a) Struktur mikro titik las tanpa preheat dan post heat ; (b) Struktur mikro titik las preheat dan post heat $130^{\circ} \mathrm{C}$; (c) Struktur mikro titik las preheat dan post heat $160^{\circ} \mathrm{C}$; (d) Struktur mikro titik las preheat dan post heat $190^{\circ} \mathrm{C}$
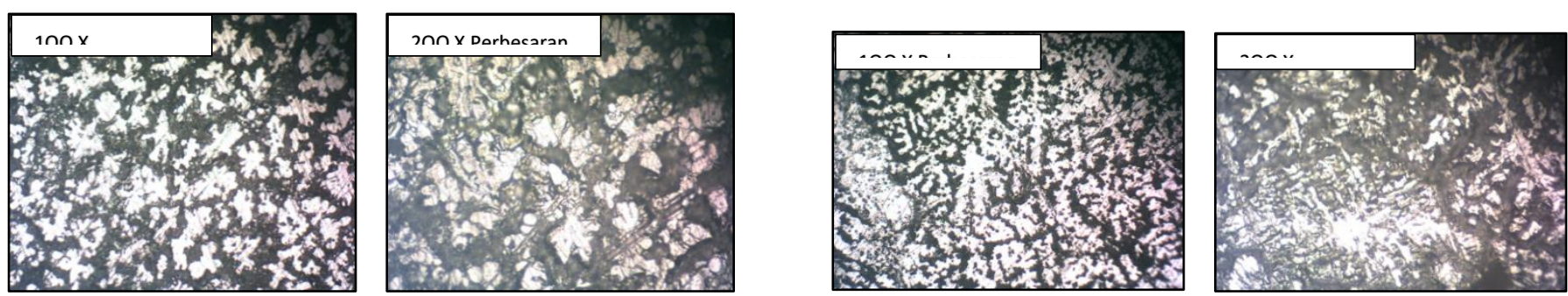
1. Pemberian perlakuan preheat dan post heat pada pengelasan Aluminium 6061 menggunakan las TIG menaikkan nilai kekerasan serta meningkatkan kekuatan tarik. Kenaikan tertinggi terletak pada pemberian variasi preheat dan post heat pada temperatur $190^{\circ} \mathrm{C}$ pada studi ini. Serta sifat elongasi akibat perlakuan panas meningkatakan nilai regangannya dan menurunkan modulus elastisitanya yang menyebabkan menurunnya sifat kekakauan dari spesimen.

2. Pemberian preheat dan post heat mempengaruhi sifat mekanik dari hasil pengelasan Aluminium 6061 dengan pengelasan Tungsten Inert Gas (TIG)

3. Perlakuan preheat dan post heat juga meningkatkan kelarutan dari $\mathrm{Mg}_{2} \mathrm{Si}$ (Magnesium dan Silikon) yang mengakibatkan meningkatnya sifat kekerasan dari spesimen

\section{Saran}

1. Pada proses pengelasan aluminium 6061 menggunakan Las TIG harus lebih memperhatikan parameter pengelasan supaya meminimalisir faktor yang dapat mempengaruhi hasil lasan. Serta kemampuan melakukan pengelasan yang baik.

2. Pada proses pengujian sebaikknya lebih teliti lagi, apalagi menggunakan mesin pengujian yang masih manual, maka sebaiknya menggunakan mesin pengujian yang sudah komputerisasi untuk hasil yang lebih baik

3. Sebaiknya untuk penelitian berikutnya bias lebih banyak memvariasikan temperatur yang digunakan untuk mendapat hasil yang terbaik.

4. Kemampuan juru las dalam melakukan pengelasan sebaiknya lebih ditingkatkan.

\section{Referensi}

Teknologi Pengelasan logam / oleh Harsono Wiryosumarto, Toshie Okumura. Cet. 8 Jakarta :Pradnya Paramita, 2000

Wiryosumarto, H, Okumurha T.,2004, Teknologi Pengelasan logam,cetakan ke-8 ,Pradnya Paramita, Jakarta

Dieter George E. 1987. Metalurgi Mekanik. Jakarta : Erlangga.Wiryosumarto, H, 2000. Teknologi Pengelasan Logam, Erlangga. Jakarta

Mahros Darsin1) Salahuddin Junus2) Yopi Indra Triawan3). Analisa Sifat Mekanik dan Struktur Mikro Paduan Aluminium 5083 Akibat Pengelasan Metal Inert Gas (MIG) Dengan Variasi Preheat dan Post Heat.

Achmad Arifin1) Heru Santoso B.R.2) M. Noer Ilman3). Pengaruh Preheat Terhadap Struktur Mikro dan Sifat Mekanis Sambungan Las GTAW Material Paduan 12Cr1MoV yang Digunakan Pada Superheater Boiler. 